\title{
A TURIZMUS TERMÉSZETFÖLDRAJZI ADOTTSÁGAI A
}

\section{BALATONNÁL}

\section{DIE NATURGEOGRAPHISCHE GEGEBENHEITEN DES TOURISMUS BEI DEM BALATON}

Dr. Lőke Zsuzsanna PhD

egyetemi adjunktus

Pannon Egyetem Georgikon Kar, Nyugat-Balatoni Társadalomtudományi Kutatócsoport

H-8360 Keszthely, Deák F. utca 16. Tel.: 06/83/545-004 Fax: 06/83/545-143 E-mail: loke@georgikon.hu 


\title{
A TURIZMUS TERMÉSZETFÖLDRAJZI ADOTTSÁGAI A
}

\author{
BALATONNÁL \\ DIE NATURGEOGRAPHISCHE GEGEBENHEITEN DES TOURISMUS
}

BEI DEM BALATON

Kulcsszavak: turizmusföldrajz, természeti erőforrások, klimatikus adottságok, szezon, vizisportok

\section{Kivonat:}

Jelen tanulmányban a balatoni turizmus természeti erőforrásait vesszük számba, különös tekintettel a klimatikus adottságokra a KSH, korábbi tanulmányok és az OMSZ hivatalos kiadványaira támaszkodva. A Balaton, Magyarország legnagyobb tava $\left(589 \mathrm{~km}^{2}\right)$ három éghajlati zóna (a kontinentális, az óceáni és a mediterrán) ütközőpontján helyezkedik el. Ennek eredményeként a tó időjárása meglehetősen változékony. Siófok és Keszthely meteorológiai adataira támaszkodva vizsgáltuk a nyári szezon meteorológiai értelemben vett hosszát és annak a turizmusra gyakorolt hatását.

Európa más tavaihoz képest kedvezőek a Balaton adottságai, sekély volta miatt vize gyorsan felmelegszik, és a vízi - sportok, a hagyományos értelemben vett fürdőzés számára (májustólszeptemberig) 5 hónapos szezont biztosít. A főszezon jelenlegi 2 hónapos, de egyes szerzők szerinti mindössze 6 hetes időtartamával szemben jelentős kontrasztban áll a tó kedvező de nem kellőképpen kiaknázott klimatikus adottsága. A fő tevékenységet, a fürdőturizmust legjobb esetben is 5 hónapra lehet kinyújtani. Ugyanakkor a szezon további hosszabbításakor a meteorológiai adottságok tükrében a turizmus más ágaira kell alapozni, mint a lovas turizmus, a túrázás, biciklizés vagy a borturizmus, illetve a szezonalitásmentes egészségturizmus. A tó környékének sajátos mikroklímája és tiszta levegője révén a turisztikai desztinációválasztás egész évben lehetséges. Ha egész évi turizmusban gondolkodunk, tudatos fejlesztésre van szükség, melynél figyelembe kell venni olyan desztinációk tapasztalatait, amelyek ezt a problémát sikeresen túlhaladták.

Schlüsselwörter: Tourismusgeographie, natürliche Gegebenheiten, klimatischen Gegebenheiten, Saison, Wassersports

\section{Auszug:}

In dieser Studie die naturgeographische Gegebenheiten Tourismus bei der Balaton dargelegt werden mit Rücksicht auf der klimatischen Verhältnissen der gegend, auf Grund von Daten des Meteorolgischen Dienstes (OMSZ) und des Staatlichen Statistischen Amts (KSH) sowie auf Grund von früheren Studien.

Der Balaton, Ungarns größter See $\left(589 \mathrm{~km}^{2}\right)$ liegt am Treffpunkt von drei klimatischen Zonen (die kontinentalen, die ozeanischen und mediterranen Zonen). Demnach die Witterung des 
Sees ist ziemlich veränderlich. Wir haben also die Dauer der Sommersaison in meteorologischen Hinsicht studiert, sowie deren Effekt auf dem Tourismus.

Im Verhältnis zu anderen europäischen Seen, sind die Gegebenheiten des Balatons günstig: das flache Wasser erwärmt sich schnell, so ermőglicht eine fünfmonatige Saison (von Mai bis September) für Wassersports und für die traditionelle Bäderei. Die gegenwärtige nur zweimonatige Saison (nach einige Autoren sogar nur 6 Woche lang) steht in wesentlichen Kontrast zu der günstigen, aber nicht richtig ausgenutzten klimatischen Gegebenheiten des Sees. Die Haupttätigkeit, d.h. Badetourismus kann auch in besten fall nur zu 5 Monaten verlängt werden. Zur gleichen Zeit kann die Saison mit anderen Zweigen des Tourismus verlängt werden, wie Pferdetourismus, Touren, Radfahren, Weintourismus, wofür die meteorologischen Verhältnisse günstig sind, oder durch die saisonalitätsfreie Gesundheitstourismus. Die eigenartige Mikroklima und reine Luft um der See ermöglicht eine ganzjährige touristische Destinationsauswahl. Wenn wir ganzjahrige Tourismus ausbilden wollen, ist eine zielbewusste Entwicklung nötig, wo man Erfahrungen von solche Destinationen in Betracht nimmt, wo ähnliche Probleme schon früher erfolgreich gelöst wurden. 


\section{BEVEZETÉS}

A Balaton kiváló adottságokkal rendelkezik, mégis gyakran halljuk, hogy csak 4-6 hét a szezon (Edvy, 2007). A kereslet megoszlását számos tényező befolyásolja: egyrészt a földrajzi adottságokhoz kapcsolódó jellemzők, mint az éghajlati viszonyok - összhangban a látogatók időjárási preferenciáival - és ebből adódóan a régió nyári üdülőhelyi imázsa, másrészt szocio-kulturális tényezők, mint a megszokás, az iskolai szünet és a vállalati szabadságok időzítése, valamint a szolgáltatások jelentős részének klasszikus 22-es csapdája helyzetet eredményező szezonális nyitva tartása (Rátz, 2006), leggyakrabban a bűnösnek mégis az időjárás van kikiáltva.

Turizmuselméleti megközelítésben a Balaton elsődlegesen az üdülőturizmus színtere, azonban a táj adottságai lehetővé teszik, hogy számos más turisztikai termék fejlesztésére is sor kerülhessen (Puczkó L. - Rátz T. 1998). A Balaton természeti vonzerői és az arra épülő infrastruktúra már most is alkalmat biztosítanak a passzív vízparti tevékenységeken túlmutató időtöltésre (Michalkó - Vízi, 2006), mint a kerékpározás, az ökoturizmus, vízi sportok és nem utolsósorban az esős napokon is népszerü borturizmus.

A tónál a legjellemzőbb vízparti tevékenységek a napozás, a fürdés, a sétálás, a kerékpározás, a horgászat, a vízi csoportos játékok, a bulizás és a különféle vízi sportok (M.Á.S.T., 2006). A Magyar Turizmus ZRt. megbízásából készített kutatás (M.Á.S.T., 2006) fókuszcsoportos vizsgálata szerint a Balatonhoz döntően a nyarat kapcsolják. Tavasszal a csodálatos nyugalmat, ősszel a természeti szépséget és a békességet, télen a korcsolyázást emelték ki, akik nem a nyarat választották. Amikor hónapot kellett választani többségük a többiekkel együtt a július-augusztusra szavazott. Már itt szóba került, hogy augusztus 20-a után „meghal” a Balaton, a szezon tehát csak két hónapig tart. 
A szabadidős turizmust, mind időben, mind térben jelentős koncentráció jellemzi, különösen fontos kérdés az éghajlati és időjárási tényezők szerepének vizsgálata a turizmus keresleti és kínálati oldalának alakulásában (Rátz, 2006). A Balaton esetében jelen tanulmányban mi azt vizsgáltuk, hogy a rövid föszezont meghosszabbító kezdeményezések sikeréhez milyen a tó környékének meteorológiai háttere. A klíma fontos befolyásoló, amihez némi szerencse is kell. A jó közérzethez (komfortérzethez) a napsütés, a derült idő és a kellő meleg éppúgy elengedhetetlen, mint a vitorlázóknak mindemellett a szél jelenléte.

\section{ANYAG ÉS MÓDSZER}

A természetföldrajzi adottságok számbavételéhez a Balatonról széles körben megjelent publikációkra és KSH adatokra támaszkodtunk. A Balaton meteorológiai sajátosságait Siófok és Keszthely meteorológia állomások 1992-1998-as egységes észlelésen alapuló adataira támaszkodva értékeltük. Az időszak kiválasztását az indokolta, hogy ekkor nem csak a siófoki, hanem a Balaton nyugati medencéjét jól reprezentáló keszthelyi meteorológiai állomáson is kiegészült napfénytartam méréssel, felhőborítottság, zivatarok, köd jelenség stb. megfigyelésével a meteorológiai mérés. Ezt követően a keszthelyi állomáson sajnos megszünt az észlelés és automata rendszerü éghajlatkutató állomássá minősítették azt át, így Keszthelyre vonatkozóan ilyen adatok a későbbiekben nem állnak rendelkezésre. Az Országos Meteorológiai Szolgálat meteorológiai beszámolóinak meteorológiai megfigyelések havi adatait másodelemeztük egyszerü statisztikai mutatók segítségével (átlag, szórás, alsó-, és felső kvartilis, szélső értékek, \%-os eltérés). A meteorológiai jellemzők közül vizsgáltuk a havi átlaghőmérsékletet, hőségnapok, nyári napok, fagyos napok, téli napok, zord napok (1. táblázat), derült és borult napok számát, napsütéses órák havi összegét, relatív nedvességet, 
csapadék mennyiségét, csapadékos napok számát, illetve zivatar, köd, havazás és hótakaró előfordulását.

1. táblázat: A vizsgált napok meteorológiai jellemzői

\begin{tabular}{|l|l|}
\hline Höségnap & $\mathrm{T}_{\max } \geq 30^{\circ} \mathrm{C}$ \\
\hline Nyári nap & $\mathrm{T}_{\max } \geq 25^{\circ} \mathrm{C}$ \\
\hline Fagyos nap & $\mathrm{T}_{\min } \leq 0^{\circ} \mathrm{C}$ \\
\hline Téli nap & $\mathrm{T}_{\max } \leq 0^{\circ} \mathrm{C}$ \\
\hline Zord nap & $\mathrm{T}_{\min } \leq-10^{\circ} \mathrm{C}$ \\
\hline
\end{tabular}

Hivatkozunk a primer adatgyüjtéssel 2009-ben Keszthely-Hévíz állandó lakosságának körében végzett elégedettségvizsgálatunk egyik eredményére. A felnőtt lakosság kor és nem szerint 1\%-át reprezentáló kérdőíves lekérdezésre 2009. május-júniusában került sor (1. ábra).

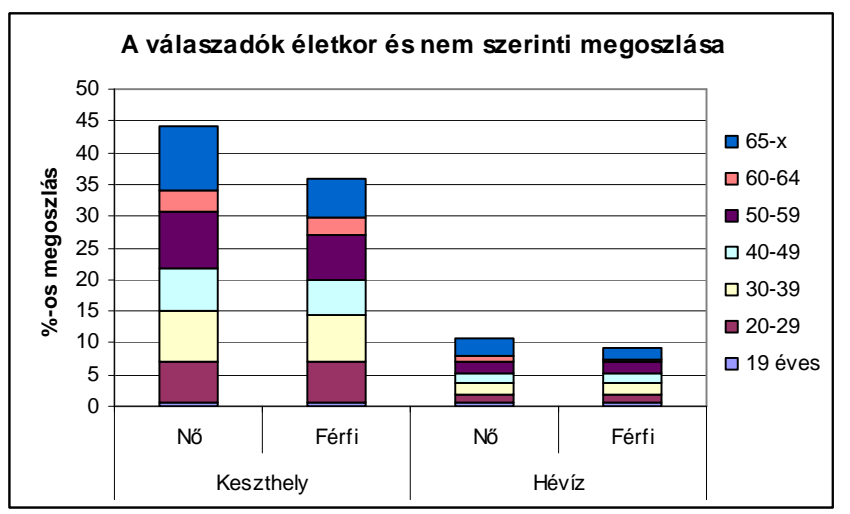

1. ábra: A válaszadók kor és nem szerinti megoszlása

\section{A TERMÉSZETFÖLDRAJZI ADOTTSÁGOK SZEREPE A TURIZMUSBAN}

A turizmus környezetét alkotó szférák az atmoszféra, a litoszféra, a hidroszféra, a bioszféra (a természetföldrajzi környezet) és a technoszféra, az épített környezet és infrastrukturális háttér. A környezetünkkel szüntelen, dinamikus kölcsönhatásban vagyunk, állandóan alakítjuk mind a makro-, mind a mikrokörnyezetünket, a (megváltoztatott) környezeti tényezők pedig visszahatnak az emberi szervezetre (Dési, 2003). 
Az emberek egészségi állapotuk javulása érdekében otthoni környezetüktől időnként merőben eltérő adottságú helyeket keresnek fel. A megszokottól eltérő klíma hatása, hogy a szervezet tartalékerejét mobilizálja, alkalmazkodóképességét növeli.

A természeti környezet fontosságának felismerése megközelítőleg egyidős a turizmusról való teoretikus gondolkodással. A turizmuselmélet által használt természeti környezet magába foglalja az élő és élettelen természet azon elemeit, amelyek közvetve vagy közvetlenül hasznosításra kerülnek, illetve amelyekben a turisztikai tevékenység hatásai kimutathatóak (Michalkó, 2004). Ezen természeti vonzerök és környezet veszélyeztetettségét a XX. századra a tömegturizmus váltotta ki. Miközben a turizmusnak köszönhetően a természetnek a korábbi évtizedek terhelésének sokszorosát kell elviselnie, addig a társadalom mindennapi élete is egyre kizsákmányoltabb környezetben zajlik (Michalkó, 2004). E kedvezőtlen változások felhívták a figyelmet a természeti erőforrások korlátozott rendelkezésre-állására, mely a kedvező adottságú turisztikai desztinációk felértékelődéséhez vezetett.

\section{A BALATON TERMÉSZETI ERÖFORRÁSAI}

A TERMÉSZETI ERŐFORRÁSOK JELENTŐSÉGE A BALATONNÁL

A Balatont és környékét mindenekelőtt a természeti (vize, élővilága) és tájértékei emelik ki a tájak sorából. A területet borító őshonos erdők jelentős részének kiírtásával mezőgazdasági tevékenységbe vonták a területet, majd a terület gazdaságosabb turisztikai hasznosítása miatt ez utóbbi is visszaszorult. Egyes napokon közel 1 millió ember tartózkodik a Balatonnál. Közel 10 millió ember látogat el évente a Balatonhoz. Ezért a tó körül koncentrálódnak az idegenforgalom gazdasági szervezetei, hogy a kedvező természeti adottságot kiaknázzák. Telepítő tényező még a Balatonon túl az ásvány-, és gyógyvizek jelenléte. A tópart 
szezonális; Hévíz, Zalakaros egészségturizmusa viszont egész éves kihasználtságú, s az érintett nem parti települések a térség meghatározó szereplőivé váltak.

A Balaton természeti adottságai vitathatatlan vonzerejét képviselik a tónak. A mintegy $77 \mathrm{~km}$ hosszan délnyugat-északkelet irányban elnyúló tó partvidéke rendkívül változatos. A festői táj, a tiszta levegő, a tó selymes édes vize és a napfény együttesen eredményezik a Balaton idegenforgalmi értékét, melyet nem csak az ideérkező turisták, hanem az itt lakók is nagy becsben tartanak.

2009-es primer adatgyűjtésen alapuló Keszthely-Hévíz város elégedettség vizsgálat is megerősíti a térség természeti erőforrásainak jelentőségét. A Pannon Egyetem Georgikon Kar Nyugat-Balatoni Társadalomtudományi Kutatócsoport arra a kérdésére, hogy „mit tart a legfontosabbnak lakóhelyén" a keszthelyi lakosok a természeti értékeket: a Balatont és a kedvező klímát emelték ki, mely tehát nem csak a turisták, hanem a helyi lakosok számára is elsődleges érték. Ennek tükrében a keszthelyi lakosok pozitív megítélését tapasztaltuk, amikor arra kérdeztünk, hogy „Ön szerint előnyös lenne-e a térségnek, ha a Hévízi gyógytó felkerülne a világörökség listára?” a Tihanyi Apátsággal és a Káli-medencével együtt. A lakosság számára a világörökség cím több, mint ismertség és a látogatók számának növekedése, ez egyben a természeti értékek védelmének egy biztosítéka is, ezért Hévízre vonatkozóan 81,9\%, Keszthely vonatkozásában $61 \%$ nagyon előnyösnek tartotta a világörökség listára való felkerülés lehetőségét.

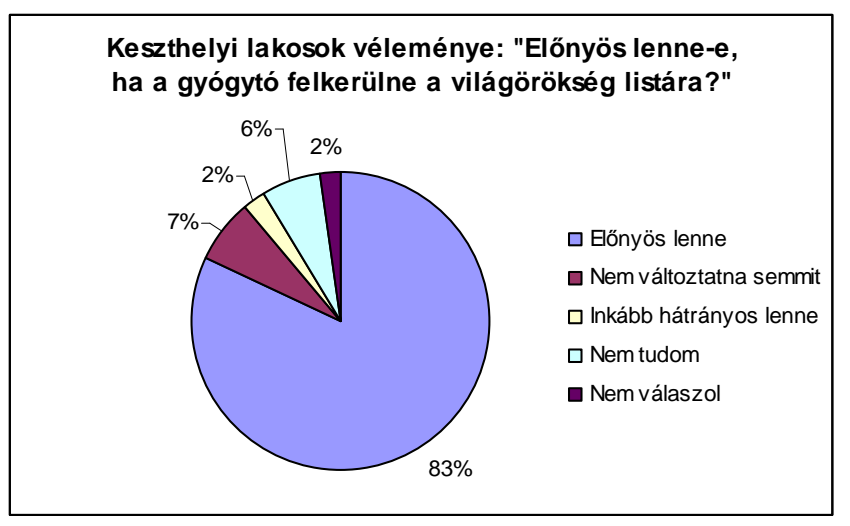


2. ábra: Keszthelyi lakosok véleményének megoszlása arról a kérdésről, hogy „Előnyös lennee ha a gyógytó felkerülne a világörökség listára?"

A térség területhasználatát a BKÜ (Balaton Kiemelt Üdülökörzet 3769 km²) területére vonatkozó statisztikai adatok alapján jellemezve: a legnagyobb vonzerő a víz, a szép táj, az erdők, szőlőültetvények, mely az elmúlt 150 év alatt az ember munkája nyomán átalakult kultúrtáj. Átlagosan 17,5 aranykorona értékűek (közepesnek mondható) a térség szántói. Jelentős agrárpotenciált a minőségi bor képvisel a térségben. Az országos átlagot meghaladja az erdősültség, a halastavak felszíne, és a nádasok. Az országos átlagtól elmarad a gyümölcs, a szántó művelési ág, de a gyep az országos átlag körüli. Bár a BKÜ erdősültsége 25,9\%, de a part menti területeknek csak 12\%-át borítja, amit levegővédelmi és esztétikai szempontból is növelni kellene (Buday-Sántha, 2007).

2. táblázat: Területhasználat a Balaton Kiemelt Üdülőkörzetben

\begin{tabular}{|c|ccccccc|}
\hline Múvelési ág & Szántó & Erdő & Szölö & Gyümölcs & Halastó & Nádas & Gyep \\
\hline Terület [ha] & 94666 & 85435 & 6000 & 1674 & 1740 & 3032 & 36285 \\
\hline
\end{tabular}

Forrás: Buday-Sántha (2007) nyomán saját szerkesztés

A turizmus központjai a tóparti települések. Ez alól kivételt azon háttértelepülések élveznek, melyek kedvező adottsággal rendelkeznek például gyógyvizük révén települt az egészségturizmus Hévízre és Zalakarosra. Az aktív pihenésre vágyóknak jó hír, hogy nem csak a Balaton-felvidéki Nemzeti Park természetvédelmi területén, hanem a tópartról induló számtalan túraútvonalon járhatjuk be a vidéket, vagy biciklizhetünk. Mód van a lovaglásra. Az országban a Balaton-felvidéken a legmagasabb az egy négyzetkilóméterre eső lovardák száma. Az egészségmegőrzés terén számos nemzetközi hírü gyógyfürdő csábít minden korosztályt egész évben a térségbe. A településeken elszórtan találunk építészeti, kulturális értékeket. 
HidROLÓGIAI ADOTTSÁGOK - MiÉRT A BALATONT VÁLASSZUK?

Korábbi kutatások is azt bizonyítják, hogy a víznek, vízpartnak húzó hatása van a turizmusban. Ösztönösen megérzésünk, hogy a víznek jó hatása van, érdemes a nyaralás helyszíneként vízpartot választani. A Balatonnál a pihentető hatás igen összetett: a táj, a megfoghatatlan színü szürkéskék víz, a víz csobogása, fényjátéka, az „,arany és ezüsthíd” látványa, ha fürdünk benne a tó állandó hullámzása és nem utolsósorban a környező táj együttese erős lelki hatást gyakorolnak. A fáradt szervezetet ezen ingerek sokasága frissíti fel. Igen elmondhatjuk a Balatonnak kifejezetten ingerklímája van.

A nyaralás során sok időt töltünk a szabadban, ha kedvező az időjárás fürdőruhára vetkőzünk, és (remélhetőleg mértékletesen) napfürdőzünk, illetve aktív testmozgással edzük szervezetünket. A tó vízfelszíne a tükröződés révén pedig még intenzívebbé teszi a napsugárzást, ami látens mozgatója a turizmusnak. Elősegíti a szervezet vitaminjainak, enzimjeinek képződését, segíti a csonterősödést, D-vitamin szintézist, és nem utolsó sorban kedvező pszichés hatása van, mely kedélyállapotunkban nyilvánul meg.

A Balaton vizének hőmérséklete igen kedvező, hiszen sekély mélysége következtében a tó egész mélységében gyorsan felmelegszik. Ha kedvező a tavaszi időjárás, már májusban fürdésre alkalmas lehet, nyár közepén pedig nem ritka a $24-27^{\circ} \mathrm{C}-o s$ vízhőmérséklet sem, mely a kontinens más tavaihoz viszonyítva hosszú akár 5 hónapos fürdési szezont biztosít. Az édesvízü tó vizének selymes jellegét az 500mg/liter körüli jellemzően kalcium-magnézium hidrogénkarbonátos oldott anyag tartalomnak köszönheti. Az északi oldal hirtelen mélyülő partjával ellentétben a déli oldal sekély vize a kisgyermekes családok számára ideális.

A Bakonyból a tóra leereszkedő szelek útjuk során örvénylő mozgásúvá válnak, mely a Balaton élénk hullámzását eredményezi. A csaknem állandó gyenge hullámzás kedvező ingerhatást vált ki, és mint gyógytényező jön számításba (Tóth, 1974). 
A váratlanul érkező balatoni viharok gyakran tragédiát is okoznak, annak ellenére, hogy a tónál - a II. Világháború alatti szünetet leszámítva - 1932 óta müködik viharjelző rendszer. Az átlagosan 3,5 méteres mélység miatt az uralkodó észak-északnyugati szél erős akár a 2 métert is elérő hullámzást tud kelteni.

\section{METEOROLÓGIAI SAJÁTOSSÁGOK}

A turista, ha nyaralni jön a legfontosabb számára a kellemes hőmérséklet. Valóban az időjárás elemei közül a hőmérsékletnek van a legnagyobb hatása a turisták tevékenységére. A vizisportok alapvetően mind meleg hőmérséklethez kötöttek, ahhoz pedig, hogy strandolni lehessen, minimum $20^{\complement C} \mathrm{C}$ feletti hömérséklet szükséges, mivel a nedves-vizes test párolgása 30-szor gyorsabb a szárazénál (Pénzes - Lőrincz, 2005). A Balatonnál május szeptember között ez teljesül, ahogy a strandok nyitva tartása is ehhez igazodik. A legmelegebb hónap az augusztus $\left(22,1^{\circ} \mathrm{C}\right.$ Siófokon, $20,7^{\circ} \mathrm{C}$ Keszthelyen).

Más tevékenységhez, aktív sportoláshoz alacsonyabb hőmérséklet kedvezőbb lehet. Ezért fontos, hogy tisztában legyünk vele, hogy az elö- és utószezon a túrázás, biciklizés számára mennyire kedvező. Siófokon már májusban meghaladja az átlaghőmérséklet a $16,9^{\circ} \mathrm{C}$-ot, és Keszthelyen is $16,1^{\circ} \mathrm{C}$ (3-4. ábra). A szeptember átlagosan Keszthelyen $15,4^{\circ} \mathrm{C}$, Siófokon $16,3{ }^{\circ} \mathrm{C}$. Bár április, és október hónapok átlaghőmérséklete eléri a $10^{\circ} \mathrm{C}$-ot, Siófok esetében ez utóbbi $11,1^{\circ} \mathrm{C}$, szerencsére is szükség van hozzá, hogy szabadtéri programunkhoz kellemes időjárás társuljon. Ekkor többnyire a fedett helyszíneket részesítjük előnyben, mert bizony mind Keszthely, mind Siófok hőmérsékleti minimumai között nulla fok alatti érték is előfordul a IV. és X. hónapban. Az évi átlaghőmérséklet Siófokon 11,1, Keszthelyen $10,5^{\circ} \mathrm{C}$. A tél enyhe, és több év átlagában a legalacsonyabb értéket képviselö január hónap átlaghőmérséklete is pozitív előjelü. 

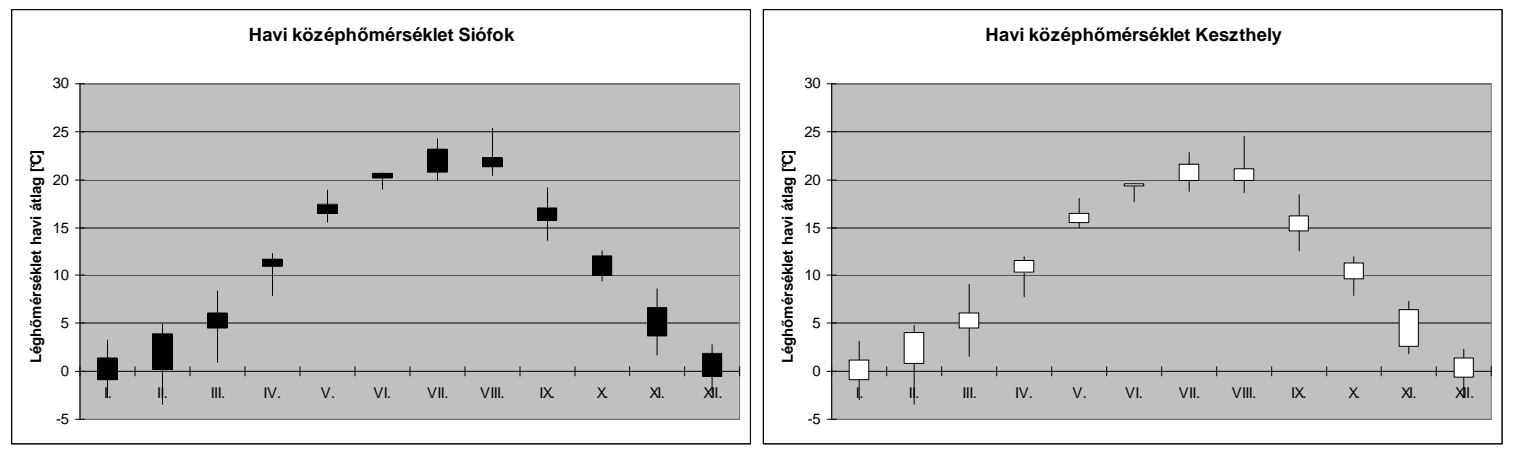

3-4. ábra: Havi középhőmérséklet alsó és felső kvartilise, illetve szélsőértékei Siófokon

(3.ábra) és Keszthelyen (4.ábra)
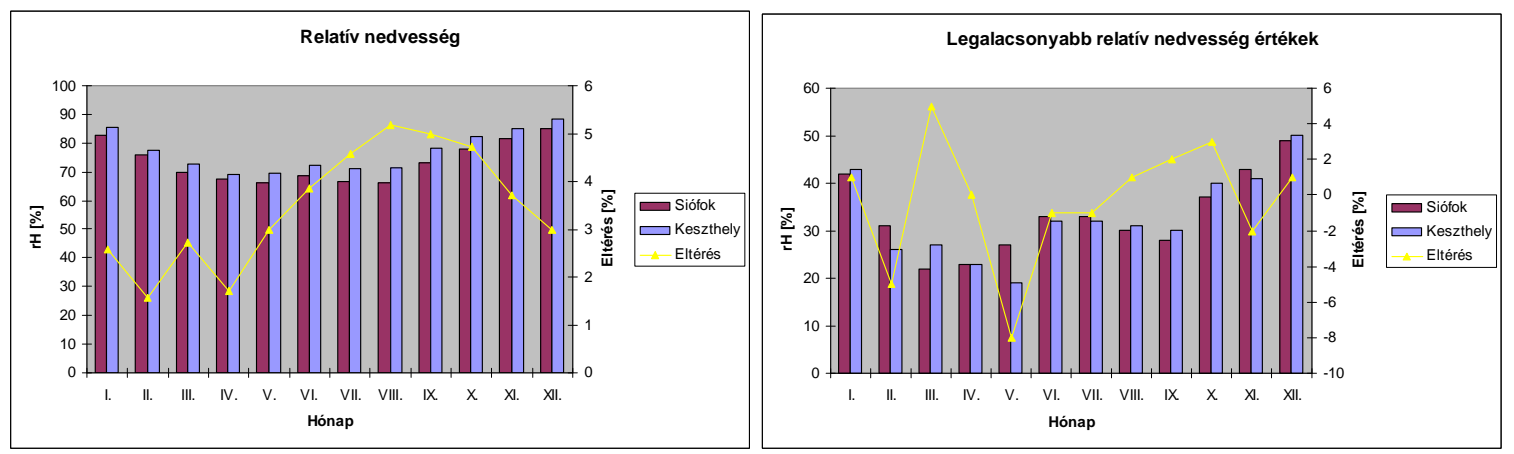

5. ábra: A relatív nedvesség havi alakulása Siófokon és Keszthelyen az eltéréssel

6. ábra: A legalacsonyabb relatív nedvességértékek havi alakulása az eltéréssel

A komfortérzetünkre a hőmérséklet és a levegő nedvességtartalma együttesen gyakorol hatást.

A Balatonnak köszönhetően a tóparti sáv levegőjének nedvességtartalma magasabb az országos átlagnál szinte valamennyi évszakban. Siófok relatív nedvesség adatai is ezt tuikrözik (73,5\%), amit Keszthelyé átlagosan 3\%-kal minden hónapban meghalad, így Keszthelyen évi átlagban 76,9\% a relatív nedvesség értéke (5. ábra).

A relatív nedvesség legalacsonyabb értékének alakulása ellenben hektikusan változik, a vizsgált 7 év abszolút rekordját Keszthely tartja 1997. május 3-i mindössze 15\%-os relatív nedvesség minimum értékkel (6. ábra). A 30\%-nál alacsonyabb relatív nedvességtartalmú száraz forróságot könnyebb elviselni, mint a nedves trópusi meleget, mely a szervezetet jelentős igénybevételnek teszi ki, amikor a víz elpárologtatása gátolt, s akár hőgutát is lehet kapni. 
A turisták azonban a veszélyek ellenére a melegre vágynak a nyaralás alatt. $25^{\circ} \mathrm{C}$-ot meghaladó maximumhőmérsékletű nyári nap átlagosan 74 van Siófokon, és 67,9 Keszthely adatainak átlagában (7-8. ábra). A $30^{\circ} \mathrm{C}$-ot meghaladó maximumú hőségnapok száma 17,1 Siófokon, míg 17,6 Keszthelyen (9-10. ábra). Az éven belül jó eséllyel a július-augusztusra tervezett nyaralás során a hónap 2/3-a nyári nap, de júniusban is átlagosan minden második nap maximumhőmérséklete eléri a $25^{\circ} \mathrm{C}$-ot. E mellett augusztusban a legnagyobb a valószínűsége, hogy igazi hőségnapnak is részesei lehetünk (Siófokon 7,8, Keszthelyen 8,3), ettől 1,5 nappal marad el a júliusi hőségnapok száma. Keszthelyen mind augusztusban (0,5 nappal), mind júliusban (1 nappal) magasabb a hőségnapok száma, mint Siófokon. A tópart kedvező hatása a tavi és parti szél, mely mérsékli a hőséget és még hőségnapon is elviselhetővé teszi a kánikulát. A tó felől nappal a szárazföld felé áramlik a nedves, hűvösebb levegő, míg éjszaka az áramlás fordított és mérsékli a lehülést.
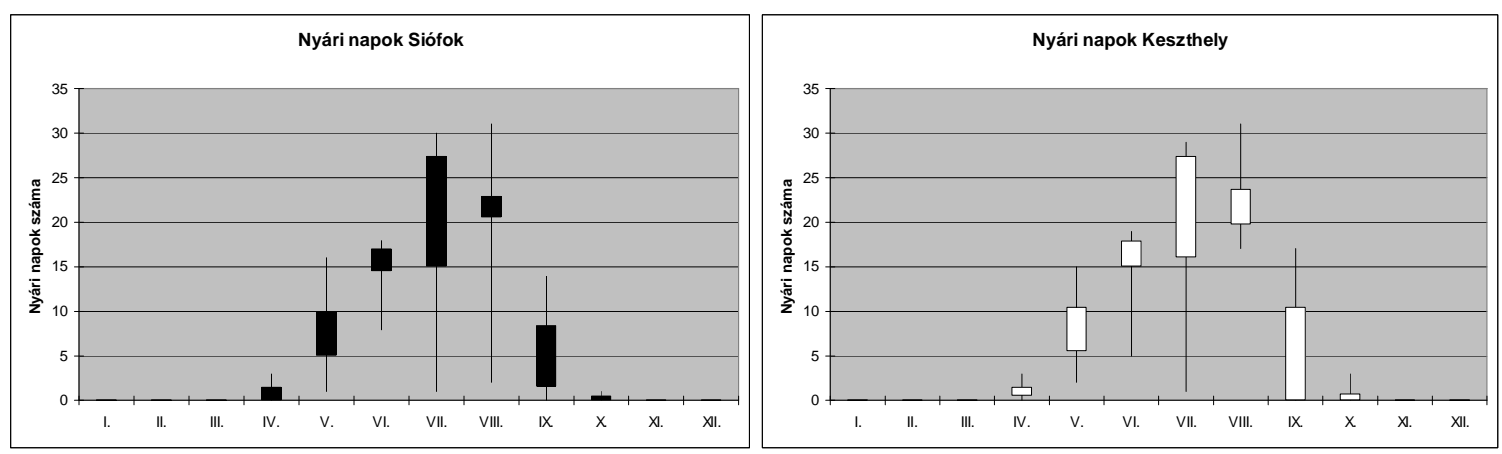

7-8. ábra: Nyári napok éven belüli előfordulása Siófokon (7. ábra) és Keszthelyen (8. ábra)
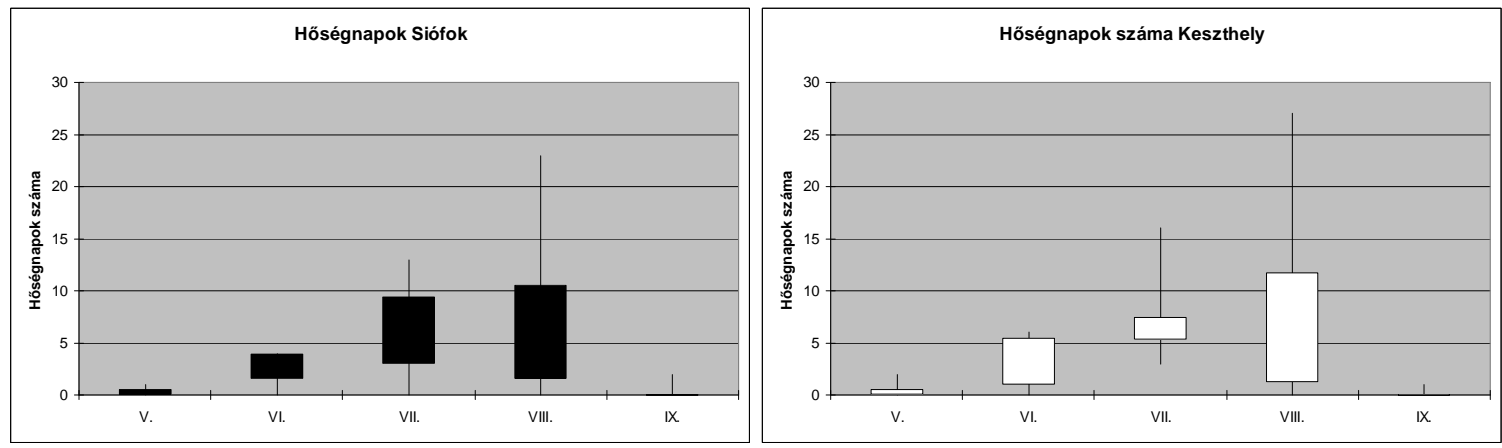

9-10. ábra: Hőségnapok éven belüli előfordulása Siófokon (9. ábra) és Keszthelyen (10. ábra)

A hőmérséklet alakulását a napsütés determinálja. A napsütéses órák száma a Balatonnál közelíti a 2100 órát (a vizsgált évek átlaga Siófokon 2080, Keszthelyen 2073,4 óra), mely 
csak kevéssel marad el az ország napfényben leggazdagabb Duna-Tisza közi tájaitól. A tó déli partja és az északi part egy része kiemelten gazdag napsütésben, ami a délies lejtőknek, a vulkanikus hegyeknek és a nyári hónapokban a borult napok kis valószínüségének köszönhetően. A 11 és 12-es ábrán jól látható, hogy májustól-augusztusig jelentős napsugárzásra lehet számítani a Balatonnál, ami a sekély víz gyors felmelegedését és könnyebb mozgásba jövetelét eredményezi. Az így keletkező hullámzás a Balatonnál tartózkodók energiabevételét tovább növeli, hiszen a hullámzó vízfelszín a sugárzás jelentős részét reflektálja, nem csak alacsony napállásnál, hanem a hullámok változó helyzete eredményeként magas napállás esetén is jelentős a visszavert sugárzás hányad egy sima vízfelszínhez képest (Tóth, 1974).

Nem véletlen, hogy fokozott figyelmet kell szentelni az OMSZ napjainkban már nem csak hőségnap, hanem UV-B sugárzás előrejelzésének, mely a fokozott UV-B sugárzás veszélyeire figyelmeztet bennünket a SOTE által kidolgozott 10 fokozatú skála segítségével.

A szeptemberi napsütéses órák száma évről-évre jelentősen ingadozik, ami nyári vénasszonyok nyarát és hirtelen ősz beköszöntét is magában rejt. A szeszélyes szeptemberrel szemben áprilisban nagyon kiegyenlítetten közel 200óra az átlagos napsütéses órák száma. A legmagasabb a napsütéses órák száma július és augusztus hónapban: Siófokon 292 és 285, Keszthelyen átlagosan 285-284óra.
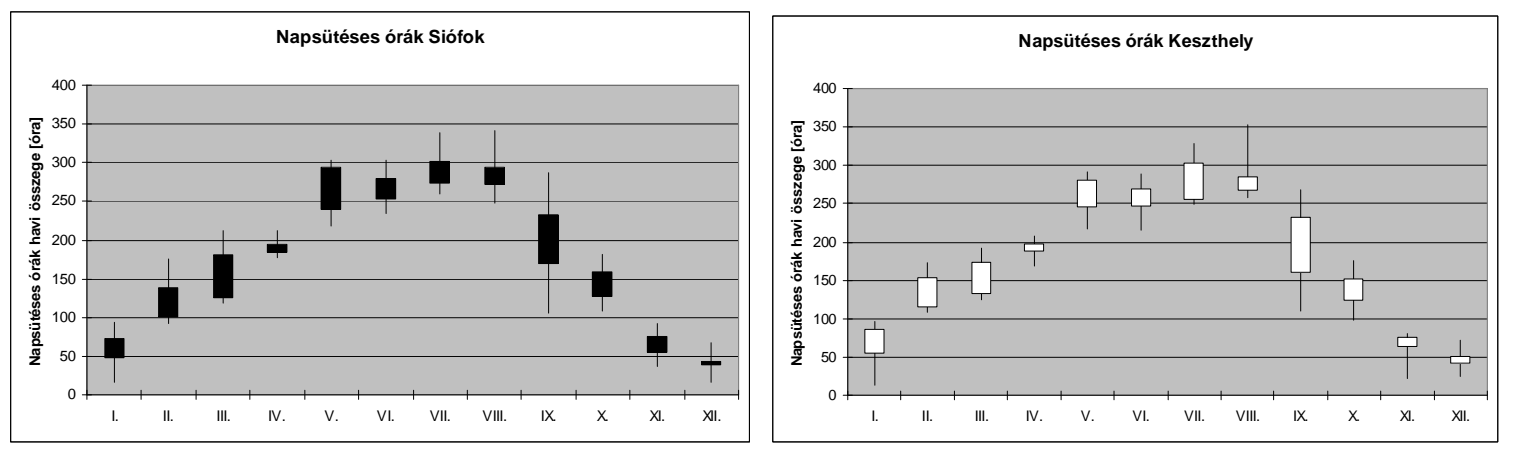

11-12. ábra: Napsütéses órák éven belüli alakulása Siófokon (11. ábra) és Keszthelyen (12. ábra) 
A zavartalan napsütést sajnos a Balatonnál nem tudjuk garantálni, habár a tó kedvező tulajdonságai közé sorolhatjuk, hogy az országban általánosan jellemző déli órákban tapasztalható felhősödés itt elmarad, az áramlási cella víz felett leszálló légmozgása következtében. A jelentős napsütés ellenére, még a legtöbb napsütéses órával bíró júliusban is átlagosan csak minden 3-dik nap derült (13. ábra). A legnagyobb valószínüsége a derült időnek augusztusban van, amikor Siófokon 13,6 nap derült (Keszthelyen 11,6). Évi átlagban Siófok 71,3 derült napot tudhat magáénak, Keszthely nyugatibb elhelyezkedése, éves magasabb csapadékhozama révén ez 58,7 derült nap.

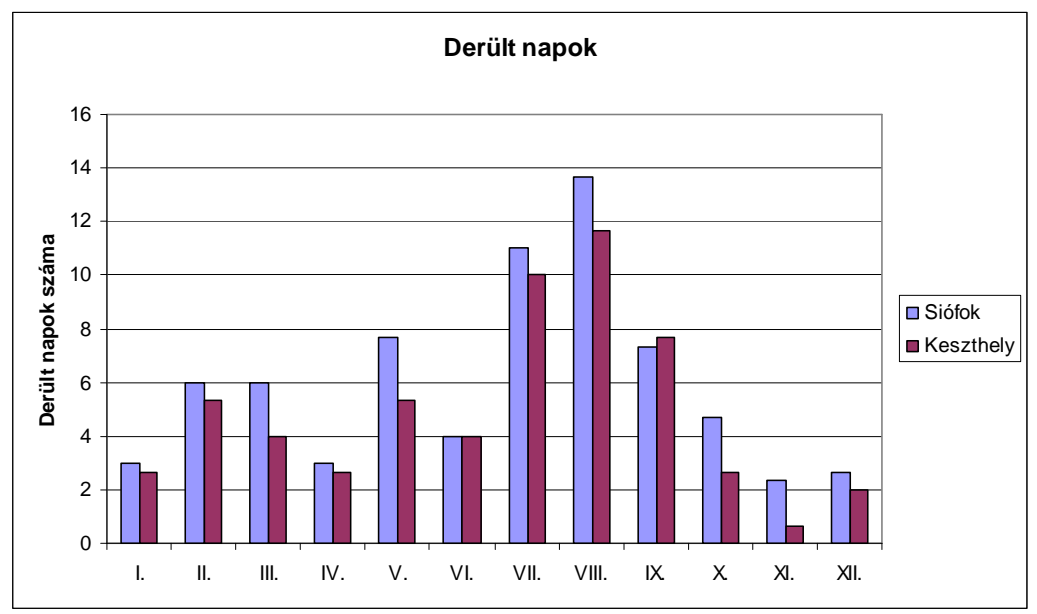

13. ábra: Derült napok éven belüli gyakorisága Siófokon és Keszthelyen

Közérzetünket a napsütésmentes, borult idő kedvezőtlenül befolyásolja. A tartós napmentes időszak a kedélyállapotunkra nyomasztóan hat, és sok embert depresszióra hajlamossá tesz. Még egy jó programot is elronthat a borult idő. Ennek legkisebb valószínűsége júliusaugusztusban és májusban van (14. ábra), de szeptemberben is átlagosan csak 4 nap borult Keszthelyen. A legtöbb borult napra Keszthelyen novemberben, Siófokon az év utolsó hónapjában kell számítani. 


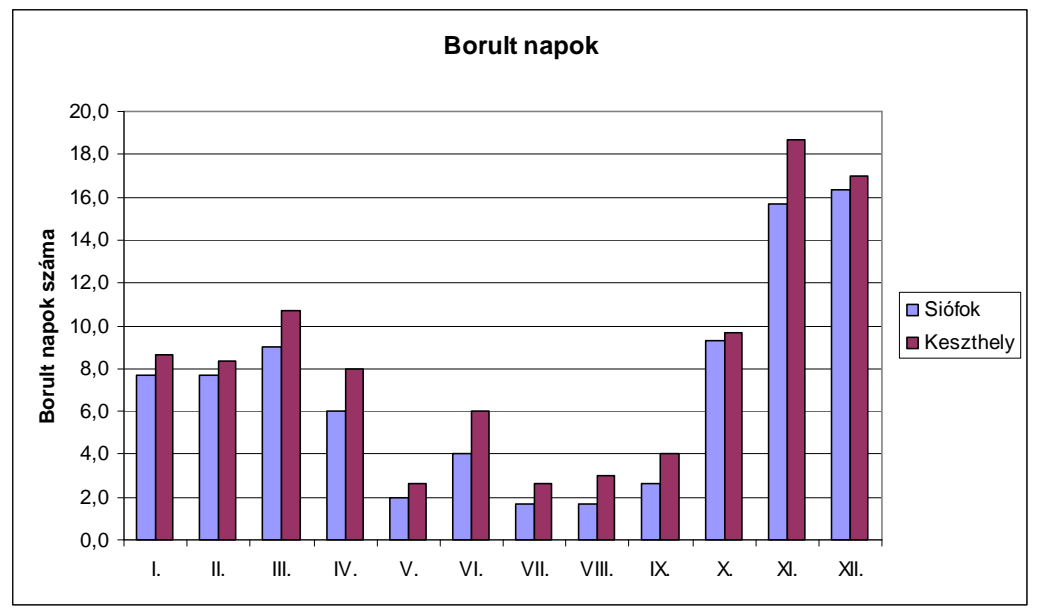

14. ábra: Borult napok éven belüli gyakorisága Siófokon és Keszthelyen

Ha a borult időjárás lehet kedvezőtlen a turizmus számára, akkor az eső, akár meghiúsítója is lehet egyes tevékenységeknek. Keszthely, és így az általa reprezentált nyugati része a Balatonnak magasabb csapadékbevétele révén a csapadékos napok számában is kedvezőtlenebb adottsággal rendelkezik. Keszthelyen a közel 100mm-rel magasabb éves csapadékbevétel évente 7\%-kal több 1mm-t meghaladó csapadékú esős napot eredményez. Az éven belüli csapadékos napok számát megvizsgálva Siófokon július-augusztusban minden harmadik napon valószínü csak csapadékesemény, május-júniusban inkább minden második napra igaz ez (15.ábra), de Keszthelyen az augusztus olyan szélsőértékek között mozog minimum 0, maximum 22 csapadékos nap - hogy az egyes évjáratok nagyon jó és kedvezőtlen nyaralóidőt is hozhatnak (16.ábra). Továbbá Keszthely adatai azt mutatják, hogy sajnos júniusban is előfordul, hogy 3 napból, akár 2 is esős lehet. A szeptember a csapadékos napok tekintetében is szeszélyes a napsütéses órákhoz hasonlóan. Mindezt az éves csapadékon belüli nyári csapadékbevételi (IV-IX. hónap) többlet eredményezi. Keszthelyen a csapadék 59,8\%-a, míg Siófokon 58\%-a a nyári félévben realizálódik, gyakran elrontva az önfeledt nyaralást. 


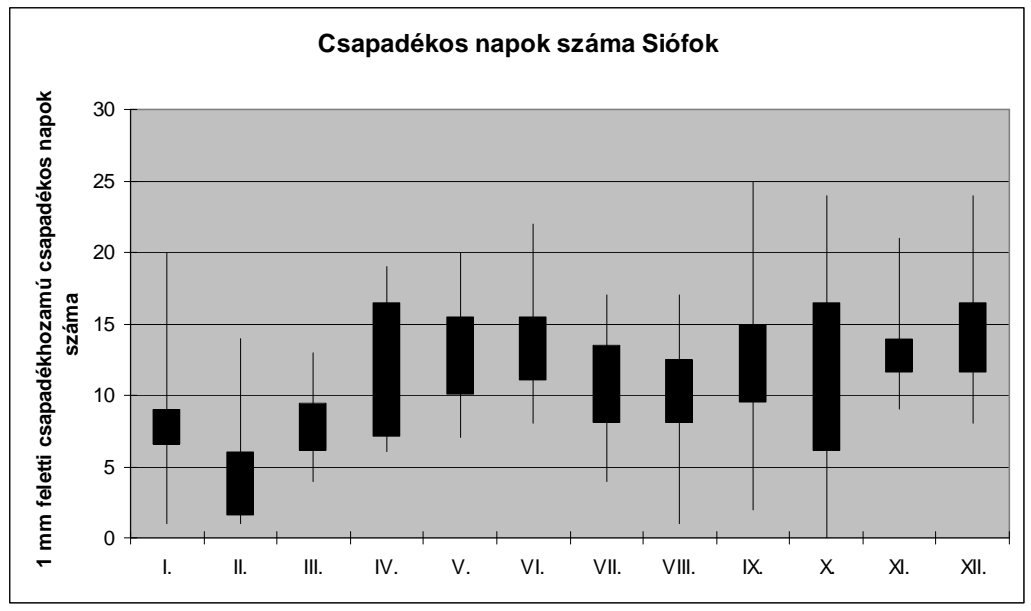

15. ábra: Az 1mm-t meghaladó csapadékhozamú csapadékos napok éven belüli alakulása

Siófokon

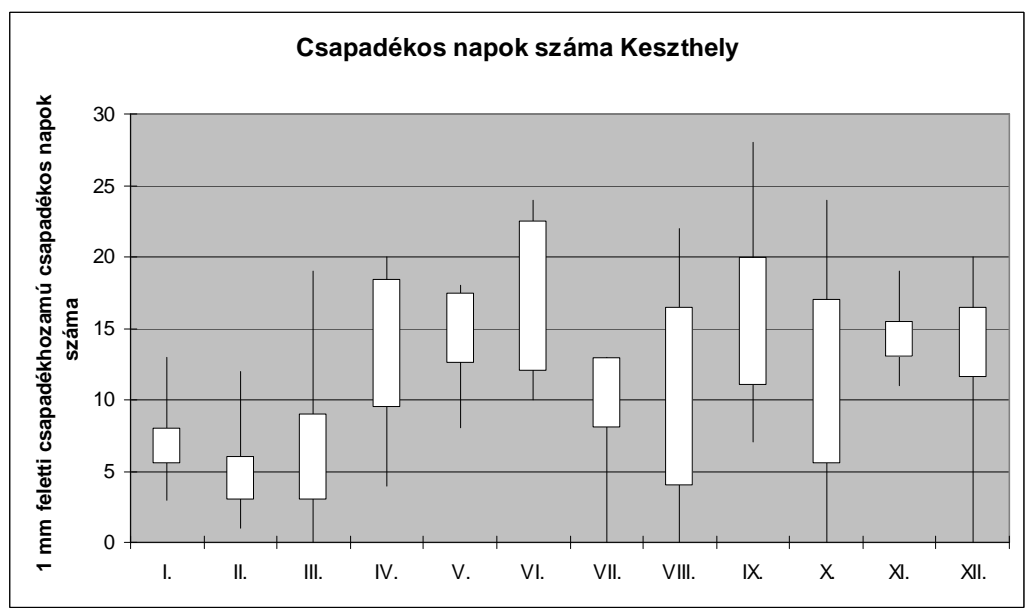

16. ábra: Az 1mm-t meghaladó csapadékhozamú csapadékos napok éven belüli alakulása Keszthelyen

Májustól a szárazföld erőteljes felmelegedésével helyi záporokból, zivatarokból jelentős csapadék hullik. Siófokon évente átlagosan 33,3, míg Keszthely térségében 31,7 zivatarra számíthatunk. Keszthelyen a zivatarok kialakulásának legnagyobb valószínüsége júniusban (6,6 alkalom), míg Siófok esetében júliusban (7,6 zivatar) van. 


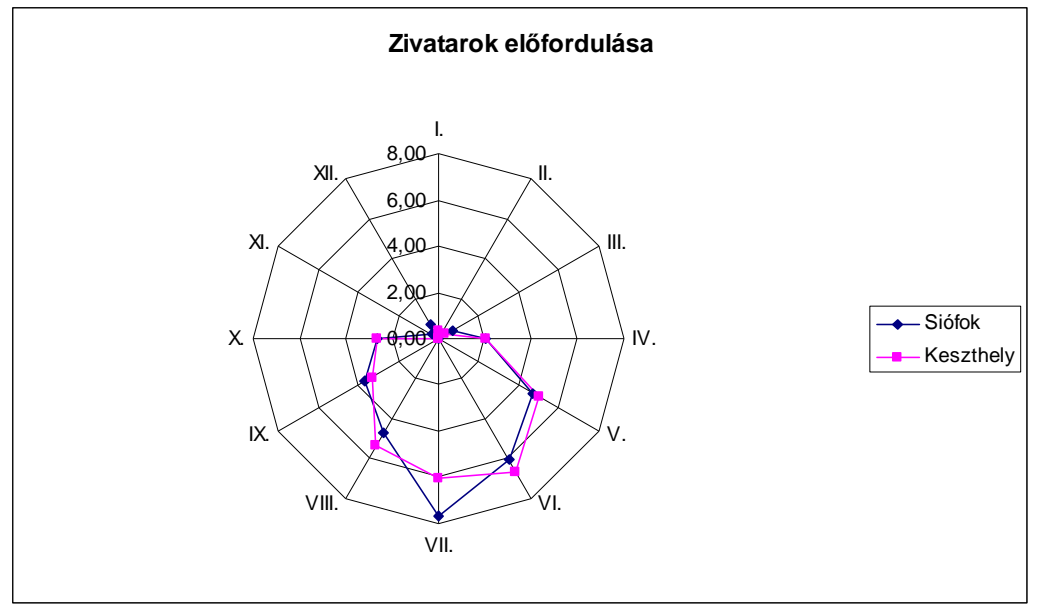

17. ábra: Zivatarok éven belüli elöfordulása Siófokon és Keszthelyen
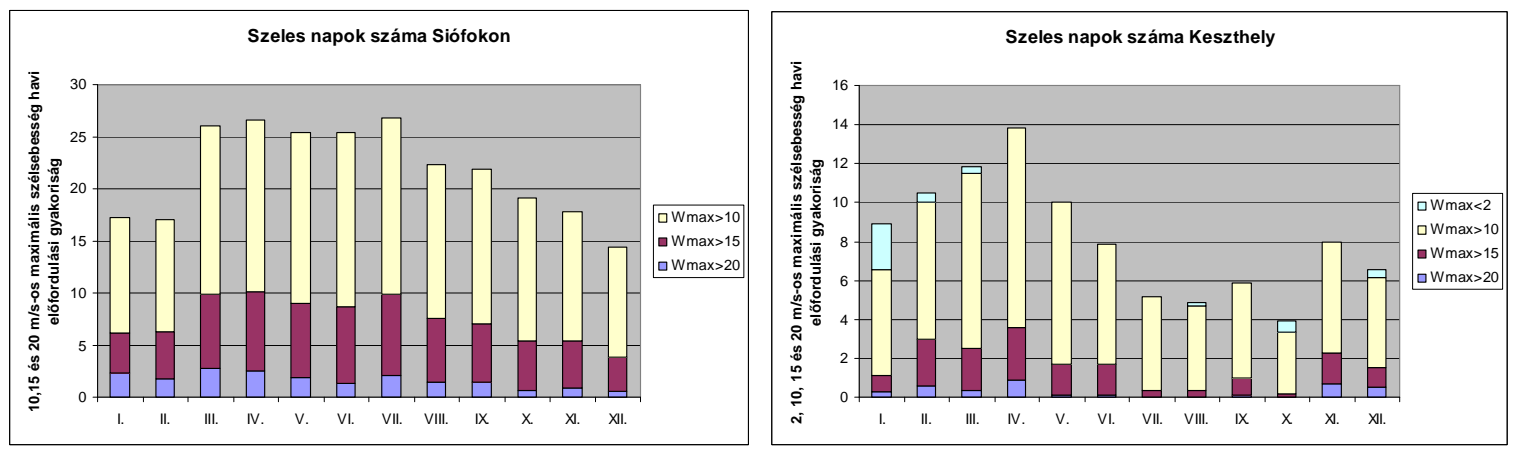

18-19. ábra: Szeles napok éven belüli előfordulása Siófokon (18. ábra) és Keszthelyen (19. ábra)

Sem a közérzetünk, sem a vitorlázósport szempontjából nem közömbös a térség szélviszonya. Az uralkodó szélirány az északnyugati, a délies irányokból pedig Siófokon délnyugati, Keszthely térségében kisebb gyakorisággal előfordul a délies áramlatok mindegyike, illetve a keleti szél is. Az időjárási frontokkal többnyire északias, a meleg beáramlással délies szélerősödések, szélviharok jelentkezhetnek. Siófokon szélcsend leginkább az őszi hónapokban fordul elő. Keszthely adataiból láthatjuk (19. ábra), hogy a csekély mértékben szeles vidéken a legélénkebb szélre április és március hónapban számíthatunk, a legcsendesebb hónap az október, de nem sokkal marad el július-szeptember sem a vitorlázók nagy bánatára. A vizisportoknál a hirtelen viharokra, felkorbácsolt hullámzásra, balesetveszélyes helyzetekre is készülni kell a szél erősödésével, amire viharjelző rendszer 
figyelmezteti az úszókat, horgászokat és a kifejezetten szélkedvelő sportok (szörf, kitesurf, vitorlázás) szerelmeseit.

A kontinentális klímahatás szélsőségeit a tó kis víztömege miatt nem képes teljesen ellensúlyozni, így kiegyenlítő hatását csak a parti sávra fejti ki, ahol tavasszal hűtő, ősszel fütő hatása érezhető. Az ország más pontjaihoz képest kiegyenlített klímájú térségben fagyos nap $\left(0^{\circ} \mathrm{C}\right.$ alatti léghőmérsékleti minimum) októbertől áprilisig fordul elő (20-21. ábra), évente átlagosan 74,9 fagyos napra számíthatunk Siófokon, és 85,3 napra Keszthelyen. Áprilisban Siófokon csupán minden második évben valószínü egy fagyos nap, Keszthelyen ez átlagosan 2,4 fagyos nap áprilisban. Októberben a tó hatása révén 2,1 és 2,6 fagyos nappal kell számolnunk Siófokon, illetve Keszthelyen. Az ún. téli nap, amikor a maximumhőmérséklet nem haladja meg a $0^{\circ} \mathrm{C}$-ot novembertől-márciusig fordul elő a Balatonnál, de ezen 5 hónap mindegyikére igaz, hogy akad olyan évjárat, amikor akár el is marad. Januárban a legvalószínübb a téli napok előfordulása, Siófokon 8,4, Keszthelyen 9,2 téli nap a januári átlag. Egy évben átlagosan 22,4 (Siófok), illetve 22,6 (Keszthely) téli nap fordul elő a vizsgált két Balaton parti meteorológiai állomáson.
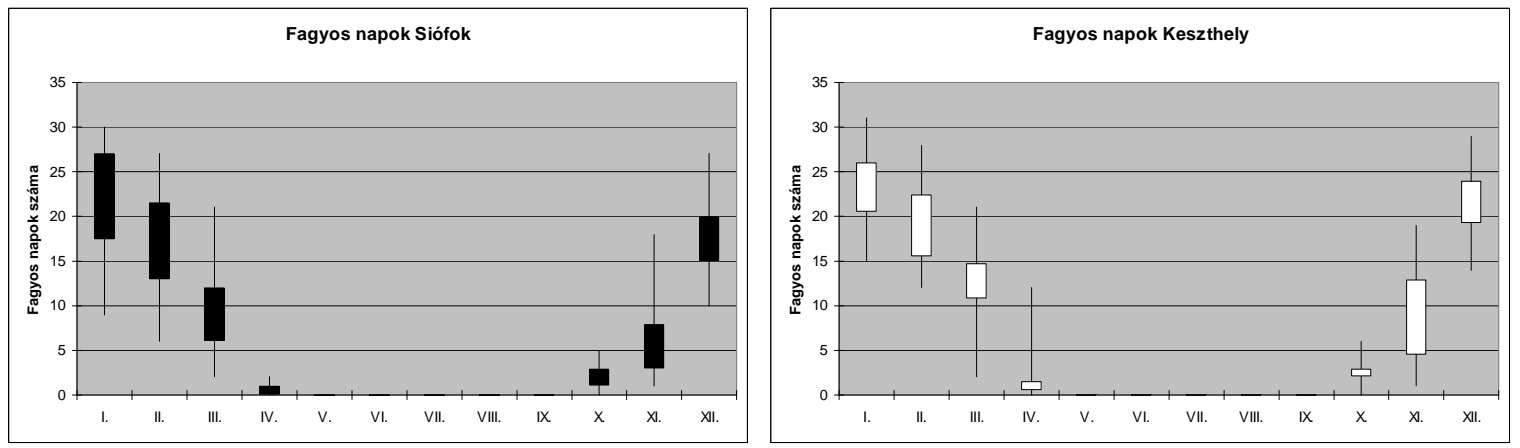

20-21. ábra: Fagyos napok éven belüli előfordulása Siófokon (20. ábra) és Keszthelyen (21. ábra)

A tó páradús környezete kedvez a ködképződésnek, mely a vizsgált évek átlagában Keszthely esetében (április kivételével) minden hónapban előfordult. Ahogy azt az alábbi 3. táblázat adatai összefoglalják, Keszthely csapadékosabb volta nem csak a ködös napok, hanem a 
havazás, és a hótakarós napok alakulásában is megnyilvánul. Évi átlagban Keszthelyen a ködös nap 69\%-kal, a havazás 21,9\%-kal, a hótakarós napok 30,5\%-kal gyakoribbak, mint Siófokon.

3. táblázat: Havazás, hótakaró és ködös napok átlagos havi előfordulása Siófokon és Keszthelyen

\begin{tabular}{|l|rrr|rrr|}
\hline & \multicolumn{3}{|c|}{ Siófok } & \multicolumn{3}{c|}{ Keszthely } \\
\cline { 2 - 7 } & havazás & hótakaró & \multicolumn{1}{c|}{ köd } & havazás & hótakaró & \multicolumn{1}{c|}{ köd } \\
\hline I. & 2,33 & 1,33 & 6,33 & 2,33 & 4,33 & 8,33 \\
II. & 3,67 & 5,33 & 5,67 & 5,33 & 5,67 & 6 \\
III. & 1,67 & 1,67 & 1,33 & 1,67 & 1,67 & 1,67 \\
IV. & 0 & 0 & 0 & 0 & 0 & 0 \\
V. & 0 & 0 & 0,33 & 0 & 0 & 0,67 \\
VI. & 0 & 0 & 0 & 0 & 0 & 1,33 \\
VII. & 0 & 0 & 0 & 0 & 0 & 0,33 \\
VIII. & 0 & 0 & 0 & 0 & 0 & 1,33 \\
IX. & 0 & 0 & 0,67 & 0 & 0 & 2,67 \\
X. & 0 & 0 & 2,67 & 0 & 0 & 10 \\
XI. & 3,33 & 4,67 & 5,67 & 3 & 4,67 & 10,33 \\
XII. & 2,67 & 6,67 & 5,33 & 4,33 & 9,33 & 4,67 \\
\hline Évi elöfordulás & 13,67 & 19,67 & 28,00 & 16,67 & 25,67 & 47,33 \\
\hline
\end{tabular}

A Balaton környékének domborzati viszonyai, mely az északi partot övező BalatonFelvidéken sem haladja meg a 450 méteres magasságot, sem a tengerszint feletti magasság által determinált hótakarós napok száma nem kedvez a téli sportoknak. Havazás átlagosan 14 és 17 alkalommal fordul elő a térségben, és a hótakaróval borított napok száma is mindössze 19,7 és 25,7 nap. Sajnos nem minden évben fagy be a tó, de ha mégis szerencséjük van a korcsolyázás szerelmeseinek, akkor akár 20-30cm (de előfordult már, hogy 60cm) vastag jégen hódolhatnak a téli sportoknak: korcsolyázásnak, fakutyának, jégvitorlázásnak.

\section{KÖVETKEZTETÉS}

A Balaton Közép-Európa legnagyobb édesvízi tava, Magyarország egyik legfontosabb természeti kincse. Kedvező klimatikus- és gazdag természeti adottságai révén az ország egyik legjelentősebb turisztikai célpontja, mind a külföldi, mind a belföldi turisták 
számára. A Balatonnak kifejezetten ingerklímája van, ahol természetes környezeti ingerek hatásával regenerálódik napjaink felfokozott életvitelü átlagembere.

A Balaton turizmusa egyszezonú. Habár a vizi turizmushoz a minimum $20 \smile \mathrm{C}$ feletti léghőmérséklet, és a fürdésre alkalmas vízhőmérséklet kedvező évjáratban májustólszeptemberig rendelkezésre áll, a fürdési célú szezon a tónál július-augusztus hónapra korlátozódik. Valóban a július-augusztusra tervezett nyaralás során a hónap 2/3-a nagy valószínüséggel nyári nap, de júniusban is átlagosan minden második nap maximumhőmérséklete eléri a $25^{\circ} \mathrm{C}$-ot. A tónál augusztusban a legnagyobb a valószínüsége, hogy igazi hőségnapnak is részesei lehetünk. A tópart kedvező hatása a tavi szél, mely még hőségnapon is elviselhetővé teszi a kánikulát. A legnagyobb valószínüsége a derült időnek augusztusban van, amikor Siófokon 13,6, míg Keszthelyen 11,6 derült napra számíthatunk. Borult nap legkisebb valószínűsége július-augusztusban és májusban van, de szeptemberben is átlagosan csak 4 nap borult Keszthelyen. Turisztikai szempontjából a Balaton keleti medencéjének kedvezőbbek a csapadékadatai (Keszthelyen 7\%-kal magasabb a csapadékos napok száma). A téli sportok számára a kiegyenlített klíma nem biztosít kedvező feltételeket, de a vizi és szabadidős turizmus számára a szezon a meteorológiai adottságok tükrében 5 hónaposra elnyújtható lenne. A térség egyedi adottsága a jelentős napsütés (a Balatonnál az éves napsütéses órák száma közelíti 2100-at), amit a tó állandóan hullámzó vízfelszíne a visszaverődés révén még megsokszoroz. A tó legfőbb vonzereje a fürdési lehetőség, de a jelenős napfény és a friss levegő a turizmus számos ágához kedvező adottságot nyújt. A szabadban végezhető tevékenységek széles spektrumához kedvező a tó környékének klimatikus adottsága és áll rendelkezésre a szükséges infrastruktúrális háttér (bicikliút, túraútvonalak, lovardák, vitorláskikötők, borrégiók-borutak). A szezon széthúzása nem csak gazdasági érdek, hanem mérsékli a főszezoni környezetterhelés mértékét. A horgászturizmus elősegíti a nem kívánatos halfajok tóból történő kiszelektálást. Az ökoturizmus nem csak 
szezont hosszabbít, hanem a turizmus ezen ága csökkenti a tavat érő terhelést, így jelentősen hozzájárul a fenntarthatósághoz. A Nemzeti Park kiemelkedő munkát végez a környezettudatosságra nevelésben. A háttértelepülések pedig az ökoturizmus révén szervesen tudnak kapcsolódni a Balaton-parti turisztikai kínálathoz. 


\section{IRODALOM}

Buday-Sántha, A. (2007): A Balaton-régió fejlesztése. Development Issues of the Balaton Region. Saldo Pénzügyi Tanácsadó és Informatikai ZRt. Budapest.

Dési, I. (2003): Környezet-egészségtan. JGYF Kiadó, Szeged.

Edvy, L. (2007): Sporttudományok és a biometeorológia a turizmus szolgálatában. „Tudomány a Sportoló Nemzetért” Konferenciasorozat 2007: A sport szerepe a turizmus fejlődésében. Keszthely, 2007. április 20-21. Magyar Sporttudományi Társaság, Előadáskivonatok p: 51.

Fekete, M. (2006): Hétköznapi turizmus. A turizmuselmélettöl a gyakorlatig. Doktori (PhD) Értekezés. Nyugat-Magyarországi egyetem Közgazdaságtudományi Kar Doktori Iskolája, Sopron.

M.Á.S.T. (2006): A Balaton imázsa a magyar lakosság körében, 2005. A Magyar Turizmus ZRt. megbízásából a M.Á.S.T. Piac- és Közvéleménykutató Társaság. Turizmus Bulletin, X, különszám: 2-17.

Michalkó, G. - Vízi I. (2006): A Balaton borturizmusának földrajzi vizsgálata. Turizmus Bulletin, X, különszám: 34-41.

Michalkó, G. (2004): A turizmuselmélet alapjai. Turizmus Akadémia 1. Kodolányi János Főiskola, Székesfehérvár. p: 218.

Országos Meteorológiai Szolgálat (1992-1998): Meteorológiai megfigyelések havi adatai. Meteorológiai beszámoló.

Pénzes, E. - Lőrincz, K. (2005): Bevezetés a turizmusföldrajzba. Egyetemi jegyzet kézirat. Veszprém. p: 35. 
Puczkó, L. - Rátz, T. (1998): A turizmus hatásai. Aula-Kodolányi János Főiskola. Budapest. pp: 491. In Michalkó G. - Vízi I. (2006): A Balaton borturizmusának földrajzi vizsgálata. Turizmus Bulletin. X, különszám: 34-41.

Puczkó, L. (1999): Turizmus és környezet. Turizmus vagy környezet? Ph.D. értekezés. Budapesti Közgazdaságtudományi Egyetem, Gazdálkodási Ph.D. program. Budapest. http://phd.lib.uni-corvinus.hu/204/01/puczko_laszlo.pdf

Rátz, T. (2006): Az éghajlati és időjárási tényezők szerepe az utazási magatartás befolyásolásában. Turizmus Bulletin. X, különszám: 42-53.

Tóth, K. (1974): Balaton monográfia. Franklin Nyomda, Budapest. Panoráma. p: 86. 